\title{
40. CHEMICAL STRATIGRAPHY OF BOREHOLES IN THE IZU-BONIN ARC FROM IN SITU NUCLEAR MEASUREMENTS ${ }^{1}$
}

\author{
M. A. Lovell, ${ }^{2}$ P. A. Pezard, ${ }^{3}$ and P. K. Harvey ${ }^{2}$
}

\begin{abstract}
In situ nuclear measurements were made in open-hole sections of Ocean Drilling Program Holes 792E and 793B. They provide quantitative estimates of a limited range of formation elements. A comparison of core and geochemical log data indicates reasonable agreements between the two. Limited analyses of a wide range of core samples indicate that although the chalk and nannofossil-rich silts are distinct, the admixture of sands, clays, and volcanogenic debris provides a range of homogeneous sediment compositions. The chemical homogeneity does not allow detailed distinct zoning on a simple chemical basis. Statistical analysis of the log data, however, reveals distinct and recognizable patterns that enable a chemostratigraphy to be derived for both sites. This chemostratigraphy is in agreement with the shipboard-derived lithologic units. It reveals considerable detail that may act as the focus for further evaluation.
\end{abstract}

\section{INTRODUCTION}

Site 792 is located on the western half of the Izu-Bonin forearc sedimentary basin, about $60 \mathrm{~km}$ east of the arc volcano Aoga Shima and $170 \mathrm{~km}$ west of the axis of the Izu-Bonin Trench. The location is upslope from a fork in the Aoga Shima Canyon, where the forearc sediments lap onto the edge of a basement high. The site was drilled five times in succession, achieving a total penetration of 885.9 mbsf; however, as a consequence of a stuck pipe, the downhole geochemistry is only in open hole from approximately this depth up to $286 \mathrm{mbsf}$. Six lithologic units were described based on the material recovered at Site 792; these are described in Table 1 (note that Unit $\mathrm{I}$ is not considered here as it does not occur in the open section of Hole 792E).

Site 793 is located in the center of the Izu-Bonin forearc sedimentary basin, $125 \mathrm{~km}$ west of the axis of the Izu-Bonin Trench; it lies in an interchannel area on the southern side of the broad Sumisu Jima Canyon. The site was drilled twice; Hole 793B was spudded with a reentry cone and penetrated to a total depth of $1682.0 \mathrm{mbsf}$. Downhole geochemical data were obtained in open hole between 1531.0 and 1034.0 mbsf. The interval between 99.7 and 586.5 mbsf was not cored; consequently, seven lithologic units were described from core obtained outside this region. These are described in Table 2, although only the lowermost Units V, VI, and VII correspond with the interval in which in situ geochemistry was measured in open hole.

In situ chemistry is measured through the deployment of a series of nuclear logging tools developed by Schlumberger. Full details of the suite of tools are given elsewhere (Hertzog et al., 1987; Anderson et al., 1990; Lovell and Anderson, 1988), but they basically consist of four measurement devices that yield intensity data for uranium, thorium, and potassium (natural gamma-spectroscopy tool); aluminum (aluminum activation tool); silicon, carbon, iron, sulfur, titanium, gadolinium, hydrogen, and chlorine (gamma spectroscopy tool). Measurements are made at $15-\mathrm{cm}$ intervals downhole and are processed into weight percent oxides (except for $\mathrm{U}, \mathrm{Th}$, and $\mathrm{Gd}$ which are measured in ppm). During processing the data are smoothed such that the individual measurements relate to a volume of rock approximately two-thirds of a meter in diameter.

\footnotetext{
'Taylor, B., Fujioka, K., et al., 1992. Proc. ODP, Sci. Results, 126: College Station, TX (Ocean Drilling Program).

${ }^{2}$ Borehole Research, Department of Geology, University of Leicester, University Road, Leicester LE1 7RH, United Kingdom.

${ }^{3}$ Institut Méditerranéen de Technologie, Département de Génie Océanique. Technopôle de Château-Gombert, 13451 Marseille Cedex 13, France.
}

The calibration of these comparatively novel geochemical logs has been the subject of considerable discussion, not least because of the difficulty of comparing different measurement techniques, sample bias in terms of volume and content, and the inherent problem created by the hostile downhole environment (see, for example, Harvey and Lovell, 1989). The chemistry of the formation is, however, important in addition to these technical difficulties. Although the log measurements have now been successfully calibrated in many sedimentary and basement formations (see, for example, Anderson et al., 1990), their application in regions of volcaniclastic sediments is hitherto not documented.

\section{CORE-LOG COMPARISON}

Table 3 presents a comparison of core and log geochemistry for a limited number of sample positions for which core was available in open-hole sections and for which geochemical logging tool (GLT) data existed. Figure 1 shows plots of core vs. GLT data for four of the oxides used in this study. In total, only seven geochemical variables were used in this preliminary study; they were chosen according to previous experience with GLT data in terms of expected primary mineralogy. A direct comparison of core and log data is difficult because of the inherent differences in the two measurement techniques, together with the errors involved in depth location of recovered core samples. Overall, however, the data show tolerably good agreement for most elements; elsewhere, however, in the sections of both holes, negative values occur in the GLT-derived values for $\mathrm{SiO}_{2}$, $\mathrm{TiO}_{2}$, and $\mathrm{CaO}$; this is a result of processing difficulties described in Pratson et al. (this volume). In particular, the large diameter hole, combined with high-porosity sediments, is detrimental to the in situ measurement, resulting in a high hydrogen signal as well as poor counting statistics for the remaining elements.

Individual comparisons show the following:

1. $\mathrm{SiO}_{2}$ has a limited range $(40 \%-60 \%)$ in the cores but a much larger range $(30 \%-75 \%)$ and typically higher $(10 \%-15 \%)$ values in the GLT data.

2. $\mathrm{Al}_{2} \mathrm{O}_{3}$ shows good agreement with most values, lying close to a 1:1 line in Figure 1. At Site 792 some GLT values appear higher than the core values.

3. Although average GLT values for $\mathrm{TiO}_{2}$ are reasonable, high $(6.8 \%)$ values in the Hole 792E GLT data have yet to be substantiated by the core data. Negative values in the GLT data are a particular problem.

4. FeO shows insignificant correlation, but the GLT data show good agreement in the $1 \%-6 \%$ range. The lack of correlation appears 
Table 1. Lithostratigraphy of Site 792.

\begin{tabular}{lcc}
\hline Unit & $\begin{array}{c}\text { Depth } \\
\text { (mbsf) }\end{array}$ & \multicolumn{1}{c}{ Description } \\
\hline I & 0-183.7 & $\begin{array}{c}\text { upper Pliocene to Holocene nannofossil-rich, } \\
\text { vitric silty clay and a clayey silt, } \\
\text { interbedded with vitric silts and sands and } \\
\text { minor pumiceous and scoriaceous gravels. }\end{array}$ \\
II & 183.7-357.4 & $\begin{array}{c}\text { middle and upper Miocene sandy mudstone, } \\
\text { muddy sandstone, and silty claystone (all } \\
\text { with nannofossil-rich claystone and } \\
\text { nannofossil chalk, and rare crystal-vitric } \\
\text { siltstone and sandstone. }\end{array}$ \\
III & $357.4-429.3$ & $\begin{array}{c}\text { upper Oligocene to middle Miocene intensely } \\
\text { bioturbated, nannofossil-rich claystone and } \\
\text { nannofossil chalk, and rare crystal-vitric } \\
\text { siltstone and sandstone. }\end{array}$ \\
IV & $429.3-783.4$ & $\begin{array}{c}\text { upper Oligocene vitric sandstone and volcanic } \\
\text { sandy conglomerate containing claystone } \\
\text { interclasts, with minor silty claystone and } \\
\text { claystone with nannofossil-rich intervals. }\end{array}$ \\
V & & $\begin{array}{c}\text { Altered volcanic sandstone with claystone } \\
\text { intraclasts. }\end{array}$ \\
VI & $804.0-885.9$ & $\begin{array}{c}\text { Porphyritic andesite with minor basaltic } \\
\text { andesite and dacite. }\end{array}$ \\
\hline
\end{tabular}

Table 2. Lithostratigraphy of Site 793.

\begin{tabular}{|c|c|c|}
\hline $\begin{array}{l}\text { Unit or } \\
\text { subunit }\end{array}$ & $\begin{array}{l}\text { Depth } \\
\text { (mbsf) }\end{array}$ & Description \\
\hline IA & $0-32.5$ & Pleistocene \\
\hline IB & $32.5-99.7$ & Sediments \\
\hline II & $586.5-591$ & Olivine-clinopyroxene-orthopyroxene diabase \\
\hline III & 591-735.7 & $\begin{array}{l}\text { lower to middle Miocene nannofossil-rich silty } \\
\text { claystone, vitric siltstone, and sandstone } \\
\text { nannofossil rich clayey siltstone. }\end{array}$ \\
\hline IV & $735.7-759.0$ & $\begin{array}{l}\text { lower Miocene claystone, nannofossil, and } \\
\text { nannofossil-rich claystone, and vitric } \\
\text { siltstone. }\end{array}$ \\
\hline V & $759.0-1373.1$ & $\begin{array}{l}\text { upper lower and upper Oligocene vitric } \\
\text { sandstone, pumiceous sandstone, granule- } \\
\text { to fine-pebble conglomerate, siltstone, } \\
\text { clayey siltstone, and silty claystone. }\end{array}$ \\
\hline VI & $1373.1-1403.9$ & $\begin{array}{l}\text { upper lower Oligocene, very poorly suited } \\
\text { volcanic breccia with sandy matrix and } \\
\text { mixed fresh to altered clasts of mainly } \\
\text { plagioclase-rich andesite. }\end{array}$ \\
\hline VII & $1403.9-1682$ & $\begin{array}{l}\text { upper-lower Oligocene breccias and massive to } \\
\text { pillowed flows of porphyritic } \\
\text { clinopyroxene-orthopyroxene and aphyric, } \\
\text { basaltic andesites and andesites. }\end{array}$ \\
\hline
\end{tabular}

to be caused by a small number of samples, mostly from Hole 792E with very high $\mathrm{FeO}$ yields. These may be real, as they are in other ODP holes where they have been associated with fracture and brecciation zones.

5. $\mathrm{CaO}$ shows reasonable but questionable agreement as a high negative value for the minimum of the full GLT data set is present. This is related to only a few sample points and is probably a consequence of overestimating the high $\mathrm{SiO}_{2}$ concentrations during the closure model.

6. $\mathrm{K}_{2} \mathrm{O}$ exhibits reasonable agreement between the GLT and core despite low concentrations.

Attempts to consider the geochemistry of individual sedimentary facies rely heavily on the results of shipboard analyses (Schlich, Wise, et al., 1990); these criteria are inevitably subject to modification following more extensive shore-based studies. Table 4 and Figure 2 show the results of a classification of the laboratory XRF data in terms of gross sedimentary description. The similarity between the majority of the units, excepting the chalk and nannofossil-rich horizons, is notable. This is accentuated when only the elements measurable downhole by the GLT are considered; the basement basaltic rock, for instance, are only clearly distinguished in Table 4 by their higher $\mathrm{MgO}$ and lower $\mathrm{Na}_{2} \mathrm{O}$ contents.

\section{DOWNHOLE GEOCHEMISTRY}

Given the apparent uniformity of the different sediments in terms of the downhole geochemistry, it is inevitable that the downhole logs show little character when compared with the main lithologic units (see Pratson et al., this volume). Figures 3 and 4 show the $\log$ responses for each hole. The main features are related respectively at each site to the location of a major fault zone and the transition into basement. In Hole 792E the dominant characteristics of the downhole geochemistry appear to be related to individual horizons that show peaks in $\mathrm{K}_{2} \mathrm{O}$, Th, and $\mathrm{U}$. An alternative approach to the variation in downhole geochemistry is to search for "natural" geochemical groups. The data have, therefore, been subjected to an iterative, nonhierarchical cluster analysis (INCA) using a Euclidean distance model on $z$-standardized measurements. Initially, 20 groups were fitted; a distinct break in the mean-squared deviation between groups occurs at Groups 11 (Hole 792E) and 12 (Hole 793B). Further details of the method are given in Lebart et al. (1984), Shepherd et al. (1987), and Harvey and Lovell (1989).

The results of these analyses are plotted in Figures 5 and 6 for Holes $792 \mathrm{E}$ and 793B, respectively. The group centroid compositions are given in Table 5 and 6 . In each case, a chemostratigraphy is derived from the relative proportions of different groups. The chemostratigraphy is also plotted in the same figures alongside the major lithologic units.

At Site 792 the derived chemostratigraphy shows excellent agreement with the shipboard descriptions. In addition to picking out each individual unit, the chemostratigraphy highlights the fault zone and the transition to basement. Indeed, the INCA classification suggests far more detail exists than originally observed; integration of these results with further detailed core descriptions and high-resolution in situ FMS images may enhance our interpretation of the chemostratigraphy. At Site 793 the open-hole section only penetrates three separate units. Again the chemostratigraphy provides far more detail, which requires both a reappraisal of the core and a consideration of finer sedimentological aspects.

Further detailed analysis of the GLT data, including an appraisal of the errors likely in this type of environment, is necessary to quantify the significance of the derived chemostratigraphy. The detailed lithostratigraphy derived from the FMS images (see Hiscott et al., this volume) will be critical in this calibration exercise, in that it provides the missing boundaries to units otherwise poorly sampled by coring.

\section{CONCLUSIONS}

A comparison of the core and geochemical log data indicates reasonable agreement between the two within the limited range of samples available for the comparison, although the estimates for silica are probably too high in the log data, and some queries still remain about the processing of the GLT data.

Initial, but very limited, geochemical data on a wide range of core samples indicate that, although the chalk and nannofossil-rich silts are not unexpectedly very distinct, the admixture of sands, clays, and volcanogenic debris leads to a range of homogeneous sediment compositions. Considerably more core-based geochemical work will be necessary to characterize these unusual sediments fully.

As a consequence of the relative chemical homogeneity among the core samples, an initial examination of the geochemical logs for both sites shows no distinct or simple pattern relating to the geology of the sites except for the recognition of a prominent fault zone and the sediment/basement interface at Site 792.

Statistical analyses of the log data have revealed, however, that distinct and recognizable patterns in the GLT logs exist from which a chemostratigraphy has been derived for both sites. The derived chemostratigraphy, at both sites, is in excellent agreement with the shipboard-derived 
Table 3. Comparison of core and geochemical logging tool (GLT) data, Holes 792E and 793B.

\begin{tabular}{|c|c|c|c|c|c|c|c|c|}
\hline & \multicolumn{4}{|c|}{ GLT } & \multicolumn{4}{|c|}{ Core } \\
\hline & Mean & SD & Min. & Max. & Mean & SD & Min. & Max. \\
\hline \multicolumn{9}{|l|}{ Hole 792E: } \\
\hline $\mathrm{SiO}_{2}$ & 57.19 & 11.15 & 30.95 & 71.48 & 47.37 & 8.71 & 16.50 & 57.99 \\
\hline $\mathrm{Al}_{2} \tilde{O}_{3}$ & 18.10 & 4.41 & 8.12 & 23.60 & 15.19 & 3.71 & 3.99 & 19.50 \\
\hline $\mathrm{TiO}_{2}$ & 0.66 & 1.08 & -2.32 & 2.48 & 0.63 & 0.19 & 0.13 & 0.87 \\
\hline $\mathrm{FeO}$ & 10.49 & 4.56 & 6.17 & 26.26 & 7.84 & 2.12 & 2.19 & 10.63 \\
\hline $\mathrm{CaO}$ & 10.24 & 8.35 & 0.83 & 34.43 & 10.39 & 8.54 & 2.40 & 40.93 \\
\hline $\mathrm{K}_{2} \mathrm{O}$ & 1.10 & 0.79 & 0.27 & 2.88 & 0.88 & 0.69 & 0.14 & 2.55 \\
\hline S & 0.81 & 3.02 & 0.00 & 14.06 & 0.15 & 0.19 & 0.05 & 1.04 \\
\hline \multicolumn{9}{|l|}{ Hole 793B: } \\
\hline $\mathrm{SiO}_{2}$ & 66.01 & 5.53 & 56.28 & 75.78 & 52.80 & 2.39 & 49.65 & 57.78 \\
\hline $\mathrm{Al}_{2} \mathrm{O}_{3}$ & 15.67 & 1.97 & 12.54 & 18.36 & 14.89 & 1.68 & 11.73 & 17.48 \\
\hline $\mathrm{TiO}_{2}$ & 1.10 & 0.35 & 0.40 & 1.55 & 0.54 & 0.14 & 0.27 & 0.74 \\
\hline $\mathrm{FeO}$ & 9.30 & 2.07 & 6.19 & 13.47 & 7.41 & 0.90 & 5.56 & 8.51 \\
\hline $\mathrm{CaO}$ & 5.95 & 2.80 & 1.23 & 12.06 & 7.65 & 1.39 & 5.31 & 9.81 \\
\hline $\mathrm{K}_{2} \mathrm{O}$ & 0.90 & 0.27 & 0.55 & 1.32 & 0.78 & 0.32 & 0.33 & 0.27 \\
\hline $\mathrm{S}$ & 1.08 & 1.30 & 0.00 & 5.28 & 0.05 & 0.03 & 0.02 & 0.12 \\
\hline
\end{tabular}

Notes: Mean for Hole 792E is $N=27$ and for Hole 793B, $N=14 . \mathrm{SD}=$ standard deviation, Min. $=$ minimum, and Max. $=$ maximum. Geochemistry of core samples was determined by XRF at the University of Nottingham.
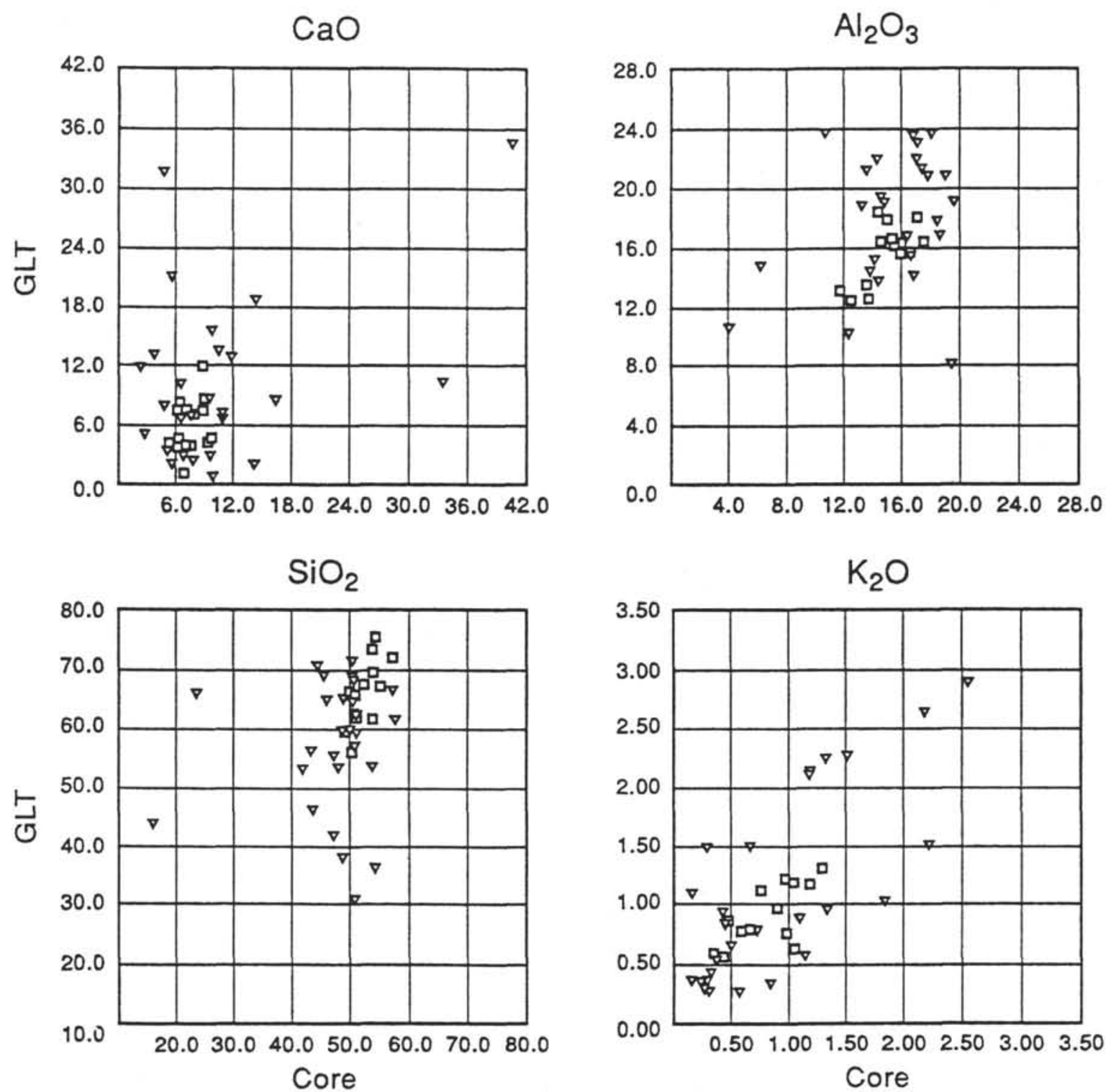

Figure 1. Comparison of core and geochemical logging tool (GLT) data. Open triangles $=$ Hole 792E, and open squares $=$ Hole $793 \mathrm{~B}$. 
Table 4. Average of core sample groups from the major lithologic units.

\begin{tabular}{|c|c|c|c|c|c|c|}
\hline & \multirow[b]{2}{*}{ Chalk } & \multicolumn{3}{|c|}{$\begin{array}{l}\text { Nannofossil-rich } \\
\text { claystone }\end{array}$} & \multirow[b]{2}{*}{ Clastics } & \multirow[b]{2}{*}{ Basalts } \\
\hline & & A & B & C & & \\
\hline $\mathrm{SiO}_{2}$ & 28.30 & 44.16 & 51.06 & 56.28 & 50.20 & 54.18 \\
\hline $\mathrm{Al}_{2} \mathrm{O}_{3}$ & 7.90 & 10.79 & 14.92 & 13.02 & 16.39 & 13.57 \\
\hline $\mathrm{TiO}_{2}$ & 0.33 & 0.45 & 0.67 & 0.64 & 0.66 & 0.37 \\
\hline $\mathrm{Fe}_{2} \mathrm{O}_{3}$ & 4.36 & 6.18 & 8.29 & 6.80 & 8.34 & 8.94 \\
\hline $\mathrm{MgO}$ & 2.63 & 2.51 & 4.77 & 3.77 & 5.56 & 8.81 \\
\hline $\mathrm{CaO}$ & 28.35 & 17.83 & 7.72 & 7.26 & 7.10 & 7.48 \\
\hline $\mathrm{Na}_{2} \mathrm{O}$ & 2.34 & 2.08 & 2.74 & 2.51 & 3.74 & 1.96 \\
\hline $\mathrm{K}_{2} \mathrm{O}$ & 0.38 & 1.01 & 1.48 & 0.97 & 0.96 & 0.87 \\
\hline $\mathrm{MnO}$ & 0.23 & 0.30 & 0.26 & 0.15 & 0.22 & 0.17 \\
\hline $\mathrm{P}_{2} \mathrm{O}_{5}$ & 0.13 & 0.12 & 0.12 & 0.11 & 0.11 & 0.01 \\
\hline LOI & 25.14 & 14.55 & 7.74 & 8.27 & 6.56 & 3.42 \\
\hline$N$ & 3 & 5 & 10 & 5 & 20 & 4 \\
\hline
\end{tabular}

$N=$ number of core samples per group. A, B, and C distinguished by visual grain-size description ranging from fine (A) to coarse (C).

Table 5. Centroid composition determined from the INCA classification of GLT responses from Hole 792E, open section.

\begin{tabular}{|c|c|c|c|c|c|c|}
\hline Group & A & B & C & D & E & $\mathrm{F}$ \\
\hline $\mathrm{SiO}_{2}$ & 55.72 & 44.66 & 45.46 & 66.32 & 69.48 & 44.40 \\
\hline $\mathrm{Al}_{2} \mathrm{O}_{3}$ & 19.64 & 14.47 & 14.97 & 11.68 & 16.58 & 14.05 \\
\hline $\mathrm{TiO}_{2}$ & 1.49 & -0.67 & 2.17 & 1.61 & 0.94 & 2.24 \\
\hline $\mathrm{FeO}$ & 10.96 & 13.47 & 16.27 & 11.42 & 14.56 & \\
\hline $\mathrm{K}_{2} \mathrm{O}$ & 0.85 & 1.50 & 0.86 & 0.63 & 0.62 & 1.07 \\
\hline $\mathrm{S}$ & 0.17 & 1.34 & 0.63 & 0.37 & 0.05 & 11.83 \\
\hline$N$ & 558 & 106 & 136 & 314 & 830 & 77 \\
\hline Group & G & H & I & J & K & \\
\hline $\mathrm{SiO}_{2}$ & 61.81 & 16.37 & 31.85 & 63.85 & 61.72 & \\
\hline $\mathrm{Al}_{2} \mathrm{O}_{3}$ & 22.42 & 17.88 & 15.61 & 16.07 & 19.08 & \\
\hline $\mathrm{TiO}_{2}$ & 1.12 & 2.84 & -0.58 & -0.05 & 1.17 & \\
\hline $\mathrm{FeO}$ & 7.79 & 23.07 & 14.09 & 8.79 & 8.05 & \\
\hline $\mathrm{CaO}$ & 5.20 & 12.60 & 24.21 & 9.16 & 6.37 & \\
\hline $\mathrm{K}_{2} \mathrm{O}$ & 0.69 & 2.08 & 1.92 & 0.89 & 2.06 & \\
\hline S & 0.08 & 20.33 & 12.68 & 0.18 & 0.16 & \\
\hline$N$ & 894 & 17 & 47 & 366 & 415 & \\
\hline
\end{tabular}

Notes: The INCA was run using a Euclidian model with z-standardization and using the GLT measurements for $\mathrm{SiO}_{2}, \mathrm{Al}_{2} \mathrm{O}_{3}$. $\mathrm{TiO}_{2}, \mathrm{FeO}, \mathrm{CaO}, \mathrm{K}_{2} \mathrm{O}$, and $\mathrm{S} . N=$ number of responses allocated to each group; number of responses classified $=3760$. lithologic units, but it is somewhat more detailed and provides a set of chemically derived units as well that will act as the focus for further evaluation of the core and other log measurements.

\section{ACKNOWLEDGMENTS}

This study uses data from Ocean Drilling Program Leg 126. The authors acknowledge the role of the shipboard staff in acquiring the data and in contributing to the success of the overall project. Particular thanks go to Beth Pratson and Robin Reynolds at Lamont-Doherty Geological Observatory and Jim Grau at Schlumberger-Doll Research for assistance in processing the data.

\section{REFERENCES}

Anderson, R. N., Dove, R. E., and Pratson, E., 1990. The calibration of geochemical well logs in basalt, granite and metamorphic rocks; and their use as a lithostratigraphic tool. In Hurst, A., Lovell, M. A., and Morton, A. C. (Eds.). Geological Applications of Wireline Logs. Spec. Pap., Geol. Soc. London, 48:177-194.

Harvey, P. K., and Lovell, M. A., 1989. Basaltic lithostratigraphy of Ocean Drilling Program Hole 504B. Nuclear Geophys., 3:87-96.

Hertzog, R. C., Colson, J. L., Seeman, B., O'Brien, M. S.., Scott, H. D., McKeon, D. C., Wraight, P. D., Grau, J. A., Ellis, D. V., Schweitzer, J. S., and Herron, M. M., 1987. Geochemical logging with spectrometry tools. Soc. Pet. Eng. Pap., 16792.

Lebart, L., Morineau, A., and Warwick, K. M., 1984. Multivariate Descriptive Statistical Analysis: New York (Wiley).

Lovell, M. A., and Anderson, R. N., 1988. When downhole logging turns to geochemistry. Geol. Today.

Schlich, R., Wise, S. W., Jr., et al., 1990. Proc. ODP, Init. Repts., 120: College Station, TX (Ocean Drilling Program).

Shepherd, A., Harvey, P. K., and Leake, R. C., 1987. The geochemistry of residual soils as an aid to geological mapping: a statistical approach. $J$. Geochem. Explor., 29:317-331.

Date of initial receipt: 28 February 1991

Date of acceptance: 17 September 1991

Ms 126B-161

Table 6. Centroid compositions determined from the INCA classification of GLT responses for Hole 793B, open section.

\begin{tabular}{|c|c|c|c|c|c|c|}
\hline Group & A & B & $\mathrm{C}$ & D & $\mathrm{E}$ & F \\
\hline $\mathrm{SiO}_{2}$ & 74.05 & 64.93 & 74.03 & 64.51 & 70.76 & 54.42 \\
\hline $\mathrm{Al}_{2} \mathrm{O}_{3}$ & 4.96 & 15.94 & 12.41 & 15.16 & 15.67 & 15.88 \\
\hline $\mathrm{TiO}_{2}$ & 0.48 & 0.84 & 0.41 & 1.12 & 0.97 & 1.05 \\
\hline $\mathrm{FeO}$ & 9.49 & 8.13 & 8.89 & 8.77 & 6.93 & 13.56 \\
\hline $\mathrm{CaO}$ & 8.90 & 8.12 & 2.80 & 4.98 & 4.24 & 5.95 \\
\hline $\mathrm{K}_{2} \mathrm{O}$ & 0.81 & 0.88 & 1.22 & 0.90 & 0.91 & 1.02 \\
\hline $\mathrm{S}$ & 1.31 & 1.18 & 0.25 & 4.5 & 0.53 & 8.09 \\
\hline$N$ & 125 & 510 & 340 & 42 & 430 & 7 \\
\hline Group & G & $\mathrm{H}$ & I & J & K & L \\
\hline $\mathrm{SiO}_{2}$ & 64.77 & 59.46 & 68.05 & 57.51 & 61.44 & 66.83 \\
\hline $\mathrm{Al}_{2} \mathrm{O}_{3}$ & 18.56 & 16.42 & 14.00 & 4.06 & 22.79 & 14.46 \\
\hline $\mathrm{TiO}_{2}$ & 1.20 & 1.14 & 0.48 & -2.36 & 1.54 & 0.62 \\
\hline $\mathrm{FeO}$ & 9.07 & 11.42 & 10.68 & 17.21 & 9.17 & 9.66 \\
\hline $\mathrm{CaO}$ & 4.95 & 9.41 & 5.29 & 19.44 & 0.41 & 5.70 \\
\hline $\mathrm{K}_{2} \mathrm{O}$ & 0.87 & 0.92 & 1.00 & 1.06 & 4.66 & 2.01 \\
\hline $\mathrm{S}$ & 0.58 & 1.23 & 0.51 & 3.10 & 0.00 & 0.73 \\
\hline$N$ & 548 & 308 & 546 & 12 & 19 & 336 \\
\hline
\end{tabular}

Notes: The INCA was run using a Euclidian model with $z$-standardization and using the GLT measurements for $\mathrm{SiO}_{2}, \mathrm{Al}_{2} \mathrm{O}_{3}$, $\mathrm{TiO}_{2}, \mathrm{FeO}, \mathrm{CaO}, \mathrm{K}_{2} \mathrm{O}$, and $\mathrm{S} . \mathrm{N}=$ number of responses allocated to each group; number of responses classified $=3198$. 


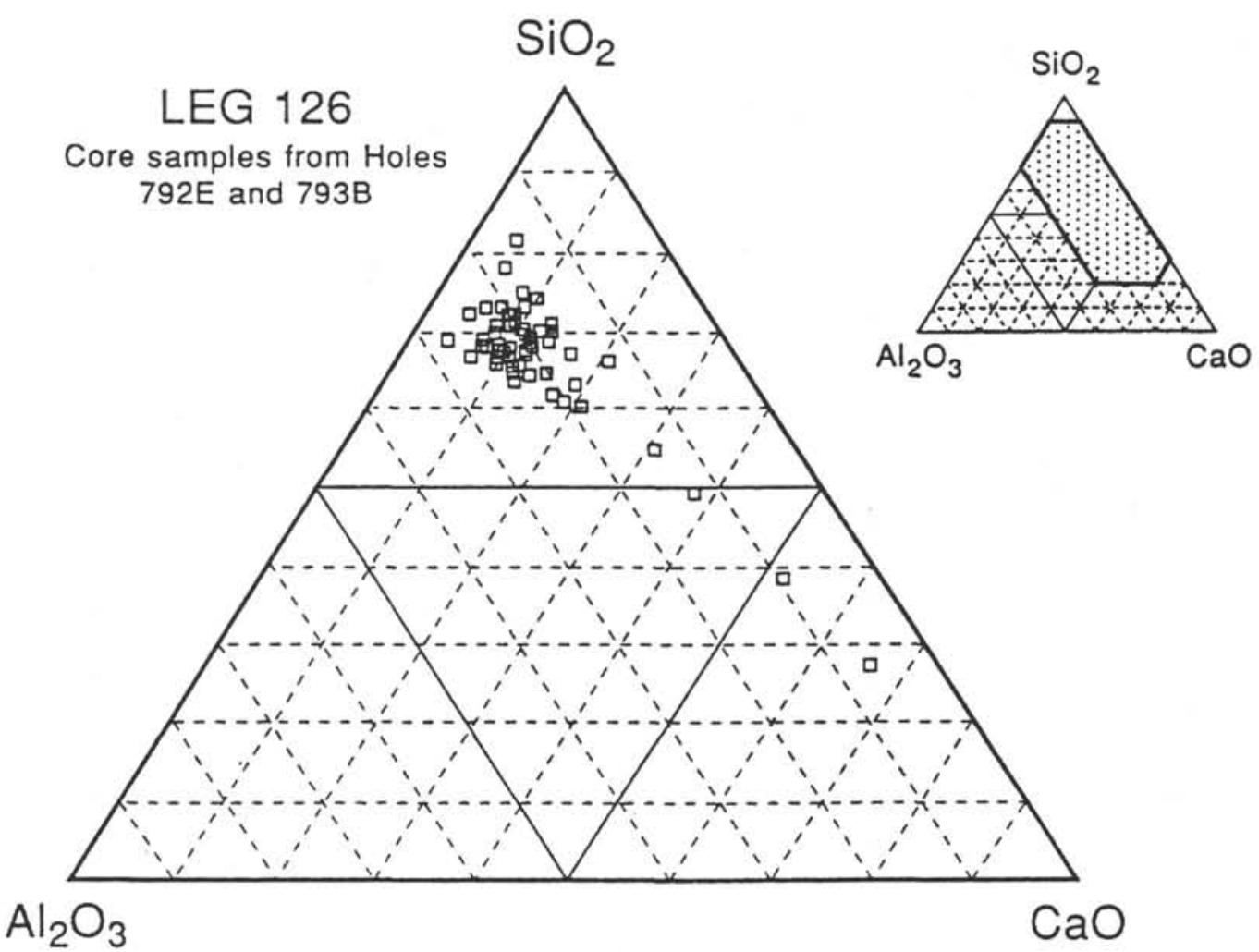

Figure 2. Geochemical classification of core samples, Holes 792E and 793B. The four points trending toward the CaO position are the nannofossil-rich claystones and chalk samples. 

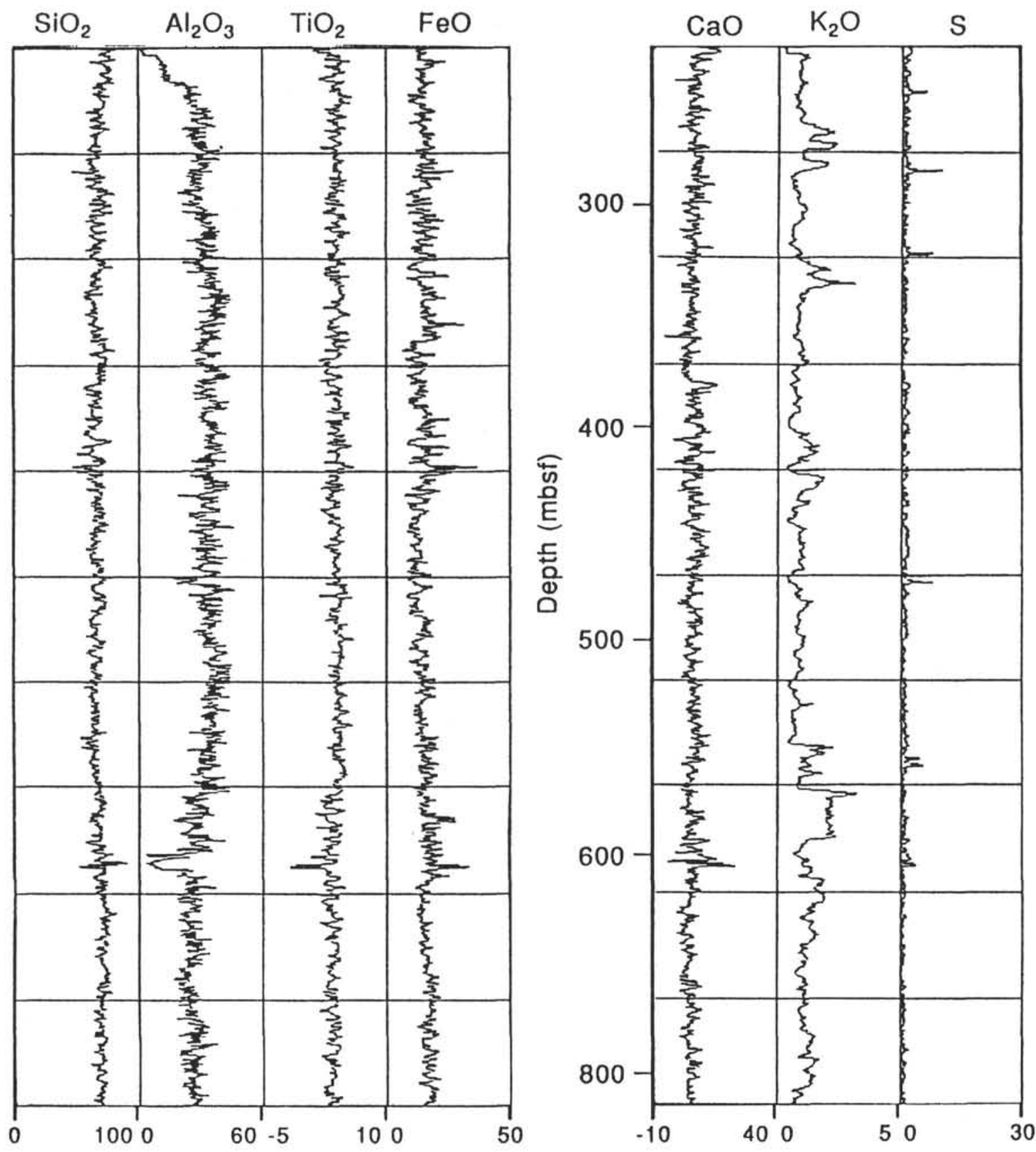

Figure 3. Downhole geochemical logs, Hole 792E. 

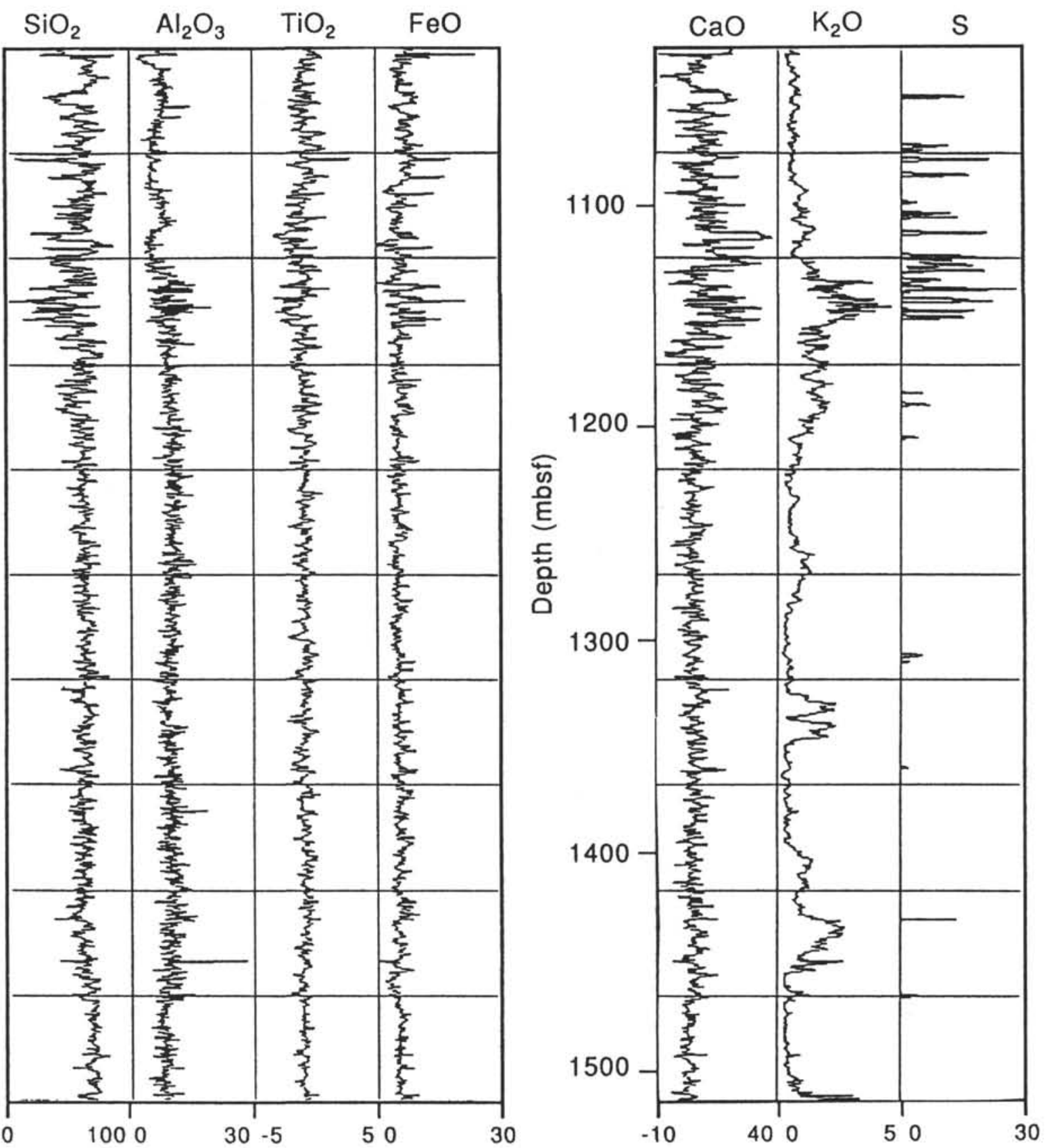

Figure 4. Downhole geochemical logs, Hole 793B. 


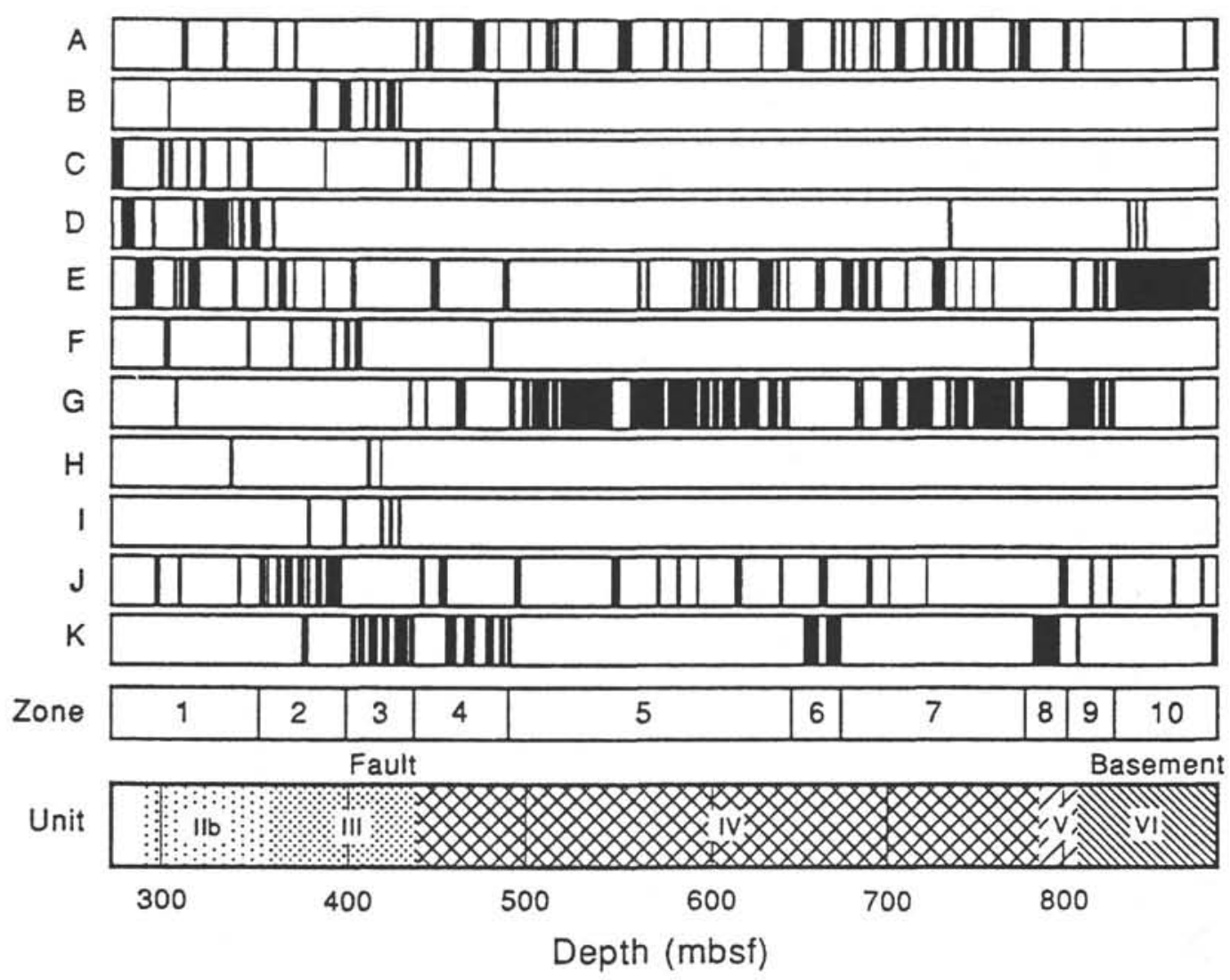

Figure 5. Site 792 iterative, nonhierarchical cluster analysis (INCA) classifications. A through $\mathrm{K}$ are different geochemical groups; INCA zones are characteristic intervals defined by these groups. 


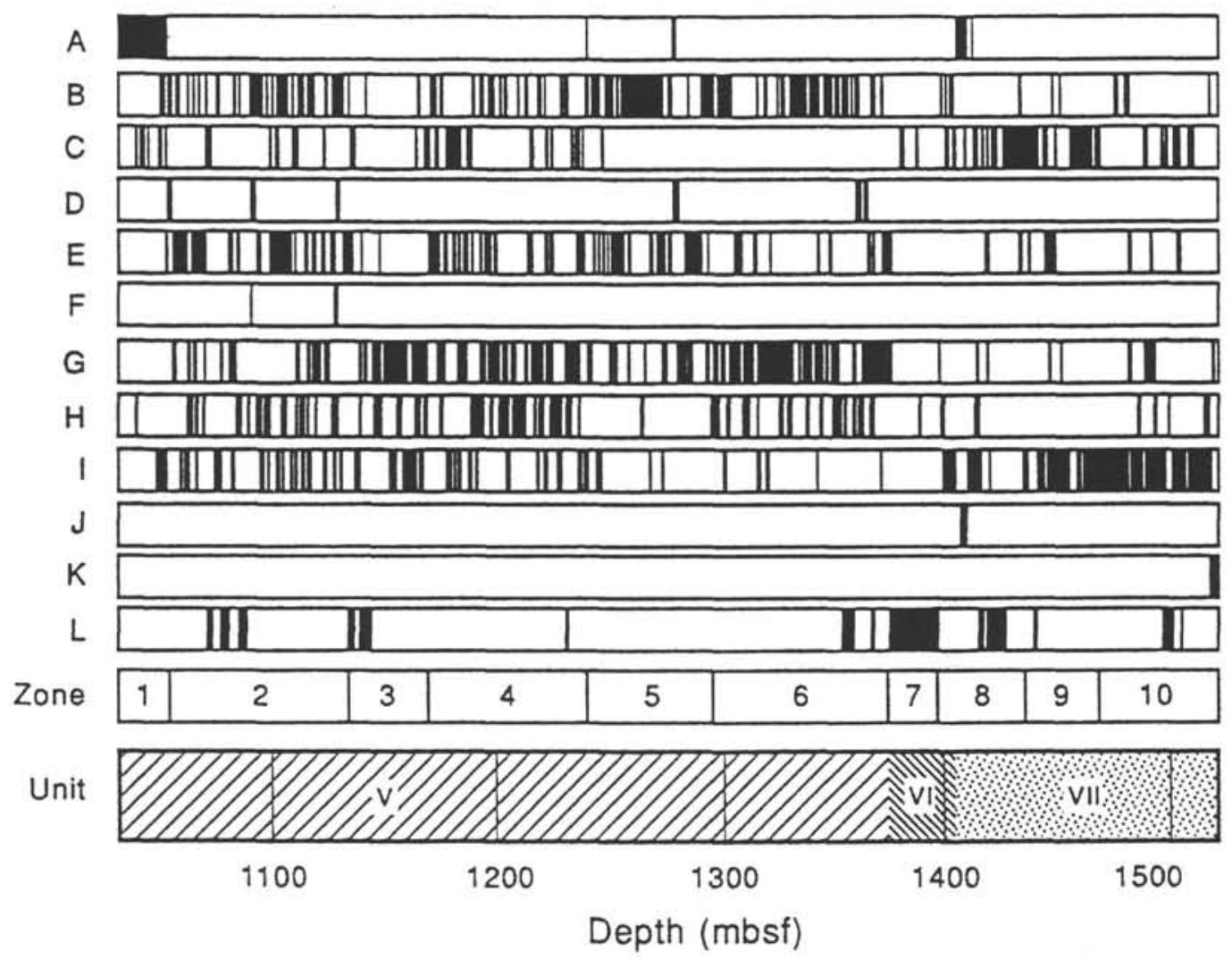

Figure 6. Site 793 iterative, nonhierarchical cluster analysis (INCA) classifications. A through L are different geochemical groups; INCA zones are characteristic intervals defined by these groups. 